\title{
The Psychological Problems and Existentialist View of the Great Two Americans Ernest Hemingway and F. Scot Fitzgerald: A Glimpses
}

\section{Sankar $\mathbf{G}^{\star}$ and Jaya K}

Department of English, SVS College of Engineering, Coimbatore, 641032, Tamil Nadu, India

*Corresponding author: Sankar G, Department of English, SVS College of Engineering, Coimbatore, 641032, Tamil Nadu, India, Tel: +919578153435 E-mail: vijaya.sankar028@gmail.com

Received date: January 25, 2016; Accepted date: March 25, 2016; Published date: March 31, 2016

Copyright: (c) 2016 Sankar G, et al. This is an open-access article distributed under the terms of the Creative Commons Attribution License, which permits unrestricted use, distribution, and reproduction in any medium, provided the original author and source are credited.

\begin{abstract}
This paper has focused the demonstration of the two great American writers, Ernest Hemingway and F. Scot Fitzgerald's experience with their own health problems, influence on their life and writing. Hemingway's weakening physical condition and increasing severe mental problems that were bipolar disorder, alcohol dependence, traumatic brain injury, and probable border line and narcissistic personality traits considerably reduced his fictional creation in the final years of his lifetime. Fitzgerald spent more than a decade of his later career, writing about illness while he struggled with tuberculosis, insomnia, alcoholism and heart disease as well as the mental illness of his wife Zelda with studying of Fitzgerald's analysis of his own life, from his stories, we are able to bring together the ineffaceable connection between personal suffering and the need for expression, between illness and identity, between writing and healing. As a result, Fitzgerald's donations to the canon of illness literature are noteworthy and as is characteristic of his career-credit for these contributions is overdue.
\end{abstract}

Keywords: Ernest Hemingway; Scott Fitzgerald; American writers; Psychology; Depression; Health sciences

\section{Introduction}

This paper is about two of the greatest writers of the world whose heritages have their own specific role in the context of the world literature. Ernest Hemingway and F. Scot Fitzgerald occupied a prominent place in the annals of American Literary history because of his revolutionary role in the arena of twentieth century American fiction but both of them had health problems that it can be seen their reflection on the writers life and works and other such environmental factors which are related with developing and possibly causing mental illness. It is thus likely that when creativity itself is associated with positive moods, happiness, and mental health, pursuing a career in the arts may bring problems with stressful environment and income [1]. Also it can be mentioned physical problems such as heart attack, liver damage, and blood pressure is other subject that can decrease creativity.

\section{Materials and Methods}

As a first step, the researcher read books and papers that present the major issues and concerned of in theme of illnesses and creativity. In the second step, the researcher read biographical work of the researcher, in the third step, did an exhaustive reading of Hemingway and Fitzgerald's major short stories and novels. As the last step the researcher studied critical works that analyses and reflect the thematic, philosophical, social, cultural and intellectual preoccupations that were revealed in Hemingway and Fitzgerald's life and works. Furthermore, in this research all of materials has been used such as digital library books, academic journal articles about Ernest Hemingway and Samuel Beckett's life and works and found background information on them in order to establish unbroken connection between their illnesses and literary heritage. In accomplishing this study, intrinsic approach and also apply descriptive analytical methods are used which combine with interpretation.

\section{Discussion}

Ernest Hemingway was a bitter and somehow harsh man who tortured his characters because he was angry that he could never find true love, or that things were not going the way he would have liked them to go in his life. It is also a fact that Hemingway was diagnosed to have a rare disease. On Hemingway's life a logical looking for a psychiatric perspective is with his family of origin. Hemingway wrote, in the memoir A Moveable Feast, "Families have many ways of being dangerous" [2], and his family was dangerous to him in different ways, not the least of that was the genetic heritage they gave to him. Ernest's father, a physician, suffered from unpredictable and dramatic mood swings characterized by episodes of depression and irritability [3]. "The Hemingway children complained of the stress their father's nervous condition placed on them, and Hemingway required repeated retreats away from the family for rest cures" [4]. "In December of 1928, in an episode of depression, feeling burdened by financial concerns and with diabetes and angina threatening his physical health, Hemingway took his life with a gunshot to the head" [5].

Ernest's mother, "Grace Hemingway, suffered from episodes of insomnia, headaches, and nerves, similar conditions have been identified in Grace's brother, Leicester, and Clarence's brother, Alfred" [3]. "Ernest, one of six siblings, was preceded in birth by his sister Marcelline and followed by Ursula, Madelaine, Carol, and his brother, Leicester" [6]. "Ursula and Leicester both died by suicide. Marcelline suffered from periods of depression, and though her death in 1963 was ruled due to natural causes, the family suspected suicide" [3]. So, it can be said the Hemingway family has a long history of health problems, and suicide that preceded Ernest's birth, claimed at least three of the six siblings in his generation, and has continued on through two 
further generations. Hemingway himself warrants a closer look "During the 1924 episode, Hemingway rapidly produced seven short stories, in 1934, he experienced another immense accession of energy, which he described as juice and found to be bad as a disease" [7]. Also the essence of Hemingway's thoughts was that in the confused and disordered world left after the Great War it is just within man's power to realize his moral purpose which must be forged and subsequently protected in the citadel of the soul. The true hero accepted responsibility for himself in a world where notions of ultimate truth and certainty had all but vanished, and with heartfelt vigor and determination he had to wring meaning out of a world devoiced of any values outside of him.

Hemingway's drinking had already started when he was a reporter, and could accept large amounts of alcohol. "Daily drinking started for Hemingway in the early1920s as his first marriage failed and escalated with the deterioration of his relationship with his mother and his father's suicide" [4]. "Then, in 1937, he presented to a physician complaining of abdominal pain, was found to have hepatic damage, and was told to abstain from alcohol" [4].

For a long time, it affected neither the quality of his writing nor his health but when he went to check up in 1937, complaining of stomach pains; liver damage was diagnosed and he was told to give up alcohol but he refused. "And seven years later, when Martha paid him a visit in hospital, she found empty liquor bottles under his bed it was time that the death knell sounded for his third marriage" [4].

The physical penance he took from alcohol was vigorously courted; the other penances were gratuitous-kidney worry from fishing in cold Spanish waters, a torn, groin muscle from something undetermined when he was staying Palencia, a finger wounded to the bone in an accident with a punch bag.

He had two airplane crashed. They were when Hemingway made up his mind to use his travel bug, going to Europe to understand some bullfights in Spain and then to Africa in the summer for one more safari with his wife Mary. They wounds were insignificant; however some of Mary's ribs were damaged. Afterwards while they were crossing the Lake Victoria by boat, they had a new flight in a de Haviland Rapide. Heading to Uganda the airplane scarcely come down the earth earlier hurtling and catching fire. Finding the door jammed, Hemingway used his head as a battering ram, butted the door twice and got out. He enjoyed being a classic example of superman pragmatism, but it nearly killed him. The smash had wounded Hemingway more than most would recognize. In this accident Hemingway's liver, spleen and right kidney were ruptured, his right arm and shoulder were disrupted, two discs of his backbone were broken, his head was fractured, his hearing and vision were damaged, his head, arms, and face were seared by the fires of the aircraft, and his muscle was paralyzed by compressed spinal column on the iliac nerve. However he lived the smashes and stayed a live to see his own early tributes, his wounds changed short his lifetime in an unhurried and hurting way.

Hemingway's creative writing can be seen as an adaptive defensive strategy for dealing with disorder moods and suicidal impulses. Baker wrote that for Hemingway, "the story ached to be told" [7]. Hemingway may have told certain stories in order to ease the aches that life started inside him. In a Farewell to Arms [8], Hemingway tells the story of a young American man, Fredrick Henry, who is wounded in the leg while serving in World War I and then falls in love with an American Red Cross nurse while he was in hospital. "Henry is wounded in the same manner and in the same geographical location as was Hemingway while he served as an ambulance driver on the Italian front" [8]. "Hemingway too fell in love with an American nurse, and the two entered into a love affair. Hemingway and his nurse likely never consummated their relationship, and though he hoped to marry her, she ultimately rejected him in a letter after his return home to Chicago" [7].

Hemingway had physical and emotional injuries with him from World War I Italy; telling the story of those wounds and applying twists of fantasy may have served a defensive role for him. In 1960, Hemingway started to lose his battle with depression and suicide. $\mathrm{He}$ wrote to Hotchner, his friend, "I'll tell you, Hotch, it is like being in a Kafka nightmare. I act cheerful like always but am not. I'm bone tired and very beat up emotionally. He began to worry that his friends were plotting to kill him and that the FBI was monitoring him" [4]. These paranoid delusions may have been due to a psychotic depression related to his bipolar illness, complicated as it likely was by chronic alcoholism and multiple traumatic brain injuries.

Hemingway was not happy in last years of his life. This superficially set off alarm bells at FBI control center, ever cautious for any mention of hostility. There were marks of psychological weakening in 1960 . He became unexpectedly concerned about money and his security. He was permitted to inter the Mayo Clinic in November of 1960, where he actually was treated by electroconvulsive therapy for several times, and he was released in January 1961. It can be said unhappy side special impact of shock therapy is the damage of memory, and for Hemingway it was a terrible loss. Deprived of his memory he could no extensive inscribe, could no longer remember the realities and pictures he need to form his skill. Inscription, that had previously turn into difficult, was now approximately unmanageable. His friends said that he got paranoia. Hemingway was persuaded that the FBI was aggressively checking his activities. In the New York Times this July 1, one of Hemingway's friends Hotchner clarified that the author "was afraid that the FBI was after him, that his body was disintegrating, that his friends had turned on him, and that living was no longer an option.

Writes Hotchner, Decades later, in response to a Freedom of Information petition, the FBI released its Hemingway file. It revealed that beginning in the 1940s Edgar Hoover had placed Ernest under surveillance because he was suspicious of Ernest's activities in Cuba [9]. Agents filed information on him and controlled his telephones over the next years. The inquiry went on all over his custody at Mary's Hospital. It can be possible that the telephone outside his room was tapped after all, Hotchner says: "In the years since, I have tried to reconcile Ernest's fear of the FBI, which I regretfully misjudged, with the reality of the FBI file, I now believe he truly sensed the surveillance and that it substantially contributed to his anguish and his suicide" $[10,11]$. As we know, author's father had committed suicide, too, but he had understood not only injured people but also so several dead men through his lifetime and we might link both of these details to Ernest Hemingway's later life that left depressed marks.

To live is the only approach to face the experimental, and the final ordeal in our lives is the conflicting of life. Boxing, war, big-game hunting, deep sea fishing, bull-fighting, totally are resources of ritualizing the death scuffle in his thoughts, it is clear in works such as A Farewell to Arms and Death in the Afternoon, which were dependent upon his own understanding. He witnessed bloody civil war one that got a prologue to World War II and prepared it the text for one of his most fruitful stories, For Whom the Bell Tolls that was modified for film in 1943. A year later, Hemingway became a war 
correspondent covering the American movement in Germany. His affection of fight took him away from comments into battle under the guise of being a correspondent. A person seeking the delight of conflict, Hemingway seemed misplaced as a person and author in peace. As he aged, more problems came forward. The text style, once renowned, looked habitually to incline into self-parody. Judgment changed against him. His book Across the River and into the Trees was extensively criticized.

His next literary creation, Islands in the Stream, printed after death in 1970, he rejected as too deprived. Not till the publication of his book The Old Man and the Sea he recuperated the name of his first profession. The novel won Hemingway the 1953 Pulitzer Prize also a year later; he received the Nobel Prize in Literature. It can be said it was, possibly, too late and little. Hemingway's alcohol consumption, continuously heroic, became worse. He suffered fits of paranoia and hopelessness. As a whole he scorned, but he underwent serious injuries. Bodily pain worsened his alcohol consumption and robbed him of his ability to work. "Hemingway's use of writing as a defense mechanism is suggested by his own words in response to reading $\mathrm{F}$. Scott Fitzgerald's article, The Crack Up, which told the tale of its writer's own struggle with depression. Hemingway thought Fitzgerald should understand work was the thing that would save him if he would only 'bite on the nail' and get down to it, honest work with honest fiction, a paragraph at a time" [7].

Fitzgerald spent more than a decade of his later career, writing about illness while he struggled with tuberculosis, insomnia, alcoholism and heart disease as well as the mental illness of his wife Zelda. In the middle of Fitzgerald's life, in 1916 he missed his junior year at Princeton because of a mild attack of malaria. In 1929 he had a tubercular hemorrhage, and $\mathrm{x}$ - rays discovered scars from attacks as early as 1919. From 1928 he was beginning to use alcohol to assist his writing, concerning it as a stimulant that would fuel his creative powers. However, it seems that he was alert of the problems that it caused him, writing that "a short story can be written on the bottle, but for a novel you need the mental speed that enables you to keep the whole pattern in your head".

During the mid-1930s, Fitzgerald's health deteriorated as his alcoholism intensified, and he was repeatedly hospitalized. In the fall of 1936 Fitzgerald suffering Hemingway's reference to him in The Snows of Kilimanjaro as a drunken, pitiful failure, tried to rededicate himself to writing. He worked intermittently on an historical novel set in ninth-century France. Begun in 1934, the novel was never completed, though Redbook Magazine bought four installments, now known as the Count of Darkness or Philippe stories. They are among the worst works of fiction Fitzgerald ever published. He had more success with Author's House and Afternoon of an Author, autobiographical essays or stories that appeared in Esquire in 1936. The following year he wrote Financing Finnegan, a story about an editor and agent who have to support a brilliant but unreliable author; the story, published by Esquire in 1938, amusingly reflects Fitzgerald's relationship with Perkins and Ober.

The short stories Fitzgerald wrote throughout the 1930s give opportunities to think about issues related to readers drawn to both literature and medicine. All through these days, his work was sated with images, characters and settings that mirrored his concern with illness and healthcare. Of particular attention are six stories Fitzgerald created during the 1930s that outstandingly feature hospitals and healthcare professionals. Though, these stories have not been wholly explored by scholars of medical humanities, lots of whom may be uninformed about their existence. These six works together with nine further stories from the 1930s are related to the field of literature and medicine since they appear illness and healthcare as the main themes in Fitzgerald's life and career and place him directly in the core of illness literature. Studied in the course of a biographical lens, these stories furthermore provide confirmation that Fitzgerald's writing was both professional and therapeutic.

Fitzgerald's work during 1930s reveals that he continually practiced illness experiences through writing. As we mentioned before, one of the first main illnesses to shape Fitzgerald's life and work was the mental illness of his wife, Zelda. "Although, Fitzgerald had been drafting the manuscript, that would gradually become Tender is the Night since 1925, his 1932 notebooks reveal that Zelda's illness was the determining factor in his final approach to the novel" [10]. This finally focused on the disintegrating marriage of this couple. Though writing from personal experience was not new to Fitzgerald, this decision to write about personal illness and suffering in both fiction and autobiography would negatively influence public reception of his work throughout the decade.

During the early 1930s, he was attacked by insomnia, depression and guilt over his wife Zelda's being committed to an asylum. In the mid-1930s suffered a mental crisis, which he detailed in a three-part essay for Esquire magazine in 1936. There is a different sort of blow that comes from within, he wrote in The Crack-Up, one that "that you don't feel until it's too late to do anything about it, until you realize with finality that in some regard you will never be as good a man again". The essay, striking for its vulnerability and insight, was trashed by critics and readers as self-indulgent and whiny [11].

Simultaneously as he was working on Tender is the Night, the illness most famous in Fitzgerald's short stories was alcoholism. Babylon Revisited and A New Leaf in 1931, Crazy Sunday (1932) and Family in the Wind (1932) reveal to unreliable extents Fitzgerald's literary exploration of the illness that was taking a firm grasp on him. Fitzgerald had been a drinker from the time when he was a young, literary star and he had written concerning alcoholics and drunks before. As Fitzgerald's alcoholism got worse all through the 1930s, yet, his alcoholic characters were no longer the young drunks of the 1920s whose drinking led to undamaging amusing as in The Camel's Back or whose initial alcoholism was an indication of a generational, ethical disillusionment as in The Beautiful and Damned. Fitzgerald's 1930s alcoholics have been collapsed by drinking. In this way, as a number of critical studies have recommended, "they mirror the type of alcoholic Fitzgerald had become" [12].

In 1935 he had another flare-up of tuberculosis. Back in the hospital in 1939, he charged the stay on tuberculosis, but friends supposed alcoholism. "Between 1932 and 1937, Fitzgerald was admitted to hospital eight times for alcoholism, chronic inactive fibroid tuberculosis, or both, and once for an ailment tentatively diagnosed as typhoid fever" [13]. Perhaps because of Fitzgerald's first-hand understanding of the disease of alcoholism, his 1930s alcoholics are among his most compelling characters of the decade. These characters involve literature and medicine readers to suspend biases, take on alien perspectives and analyze the motives of difficult or non-compliant patients-all valuable exercises in the development of empathy. Unfortunately, as Fitzgerald began to explore darker themes, "The Saturday Evening Post, which published all the early 1930s alcoholic stories except Crazy Sunday, would eventually decline Fitzgerald's work on topics like alcoholism and mental illness, considering them taboo and unsuitable for their mainstream audience". 
In a 1935 interview given to Acheville Citizen, Fitzgerald stated that his first inpatient experience at Johns Hopkins Hospital in August 1932 moved him to write about a hospital: "[I] realized after I left the place that I had been accumulating material for some writing and hadn't known it at the time, So followed One Interne [1932] a short story with a hospital as its scene." [14] Following these visits, Fitzgerald published the six doctor-nurse stories between November 1932 and March 1937. In addition to One Interne (1932), these stories include Her Last Case (1934), Zone of Accident (1935), An Alcoholic Case (1937), Trouble (1937) and In the Holidays (1937).

Edward J Gleason argues that "nearly all of Fitzgerald's Esquire stories and even his final novel The Love of the Last Tycoon offer a parade of doomed characters and are full of images and allusions that reveal Fitzgerald's depressed state of mind".

Up to his death, Zelda's mental disease informed Fitzgerald's work as much as his own declining health. His Zelda-inspired writings propose Fitzgerald never recovered from the stress, anxiety and guilt he felt over leaving his wife in an institution. His preoccupation with writing about Zelda's condition provides the chance to discuss the complex roles family members and career's play in patients' lives, especially family members struggling with their own illnesses.

Most of his life he suffered from an over secretion of insulin (hyper insulinism), which contributed to his need for alcohol. It resulted in low blood sugar as well, which explained his desire for Coca-Cola and a great deal sweetened coffee and his near addiction to fudge. Near the end of November 1940, Fitzgerald had heart breakdown related to alcoholic cardiomyopathy at a Schwab's drugstore on Sunset Boulevard and was ordered to bed rest. Despite doctor's orders he remained devoted to drafting his new novel, which would be published posthumously as The Last Tycoon optimistically believing he was on the mend. He wrote to Zelda on 13 December, 1940: "The cardiogram shows that my heart is repairing itself, but it will be a gradual process that will take some months. It is odd that the heart is one of the organs that repair itself" At last just before Christmas, 21 December, 1940, America's most eminent writer and a titan of 20th-century letters, suffered another immense heart attack and died at the age of 44 [15].

Fitzgerald is, as Petry has noted, "the greatest example of an American author whose private life is reflected, consciously or otherwise, in virtually everything he wrote" [16]. But this paper should not be full without analysis of the last works of the author. So, the first of the posthumously published works of Fitzgerald worth to be mentioned is The Love of the Last Tycoon. It would be his final treatment of themes central to his work, particularly the pursuit of the American Dream of success and the fulfillment of heroic aspirations.

This novel is commonly considered a roman a clef, enthused by the life of film producer Irving Thalberg, on whom protagonist Monroe Stahr is based on. He finds himself not only trying to get love and accomplishment in a world of cut-throats, but struggling for his own life. $\mathrm{He}$ is working unbreakable to make admirable movies and preserve his standards against aggressive studio forces. Stahr personifies Fitzgerald's image of the tycoon, the pioneer, who believed his quest had dominated American history and had supplied a model for Fitzgerald himself: "It is the history of me and of my people. And if I came here yesterday like Sheilah I should still think so. It is the history of all aspiration-not just the American dream but the human dream and if I came at the end of it that too is a place in the line of the pioneers" [17].
The novel follows Stahr's promoting power in Hollywood, and his conflicts with rival Pat Brady, a character derived from studio leader Louis B. Mayer. The comments for the novel were firstly gathered and edited by Edmund Wilson, and the uncompleted novel was published in 1941 by the title of The Last Tycoon. The title was supplied from a list of rejected working titles in Fitzgerald's comments for the novel; although there is now critical agreement that Fitzgerald planned The Love of the Last Tycoon to be the book's title. Wilson provided a text of The Last Tycoon for the common reader, accumulating the episodes into chapters. By this redacting, Wilson aimed to represent the episodes in much more completed form than in Fitzgerald's draft. He also provided a summary of the unwritten chapters and a selection of the plans and notes.

Fitzgerald, in his last novel appears to have mastered lots of the inadequacies of his preceding writings and was prepared to symbolize convincingly in The Last Tycoon the tragic ideal with which he had established his profession as a writer. The Last Tycoon remains a demonstration to Fitzgerald's literary genius. The revised edition of this novel won the Choice Outstanding Academic Books award of 1995 [18].

The next posthumously printed work is The Crack-up in August 1945. It should be noted that Fitzgerald was piously and economically at a low point in 1935. His style was losing its distinction since he didn't have time to polish his writing style. His plots had become slackly created and his heroes were unpersuasive. The supreme achievement of the human mind was perceptibly the ideal that Fitzgerald had set for himself as a writer. But the tragedy of his life was that he never attained the ultimate security for the affable personal situations that might have allowed him to achieve it [19].

At the time of his crack-up, Fitzgerald appeared to have felt that he was no more able to write even the type of stories that the magazines would prefer to publish. This drying up of his source of earnings, jointly with Zelda's weakening condition and his own worsening healthiness, made his vision undeniably bleak. He was an ill, weary, depressed man of thirty-eight who felt he had lost the capability to think deeply. For the first time in his occupation he was creating actually hack work which was different from commercial work.

"In The Crack-Up he explained that he no longer believed life was something you dominated if you were any good" but instead found him helpless and emotionally bankrupt, both as a human being and as a writer [20].

Not every person reacted badly to, or misunderstood Fitzgerald's attempts to struggle with his past in order to heal and move forward. Fitzgerald's friend Sara Murphy seemed to understand the healing effect that writing might have for him. He showed he had found some healing through writing about his personal grapples. For instance, by reflecting on failures he came across as a younger man in Handle It with Care, he was encouraged that he had previously overcome great difficulties and might again. Hemingway, particularly, was disdainful of what he considered Fitzgerald's public whining. But the 1945 CrackUp volume helped to refresh interest in Fitzgerald's work.

The essays stand today as a compelling psychological portrayal and an illustration of an important Fitzgerald theme. Published by New Directions, it was warmly received and has become a standard volume in the Fitzgerald canon. In his influential review of The Crack-Up Lionel Trilling identified Fitzgerald's heroic awareness: “The root of Fitzgerald's heroism is to be found, as it sometimes is in tragic heroes, in his power of love" [21]. "In 1999, Modern American Library asked 
scholars, critics and authors to list the greatest novels of the last 100 years. The Great Gatsby was ranked 2nd just under James Joyce's Ulysses; Tender is the Night came in 28th. Ernest Hemingway placed 45th for The Sun Also Rises and came in 74th for A Farewell to Arms [22].

Fitzgerald's 1930 decade can be considered as a dark period, in which his illness especially his alcoholism, and Zelda's hospitalization had a deep impact on his core identity and his writing, notably in Tender is the Night, Fitzgerald's personal tragedy. Despite his focusing on dark themes as, death, dysfunction and doom during these years and the public failure of some of his work, Fitzgerald is now everlastingly placed with the greatest writers who ever lived, where he wanted to be all along, where he belongs [23-25].

\section{Conclusion}

Hemingway and Fitzgerald's health problems had a significant impact on their life, works and death. The physical penance that both of them took from alcohol was vigorously courted; the other penances of Hemingway were gratuitous-kidney worry from fishing in cold Spanish waters, a torn, groin muscle from something undetermined when he was staying Palencia, a finger wounded to the bone in an accident with a punch bag. Hemingway's weakening physical condition and increasing severe mental problems considerably reduced his fictional creation in the final years of his lifetime. The last tension was when the Cuban rule of revolutionist Fidel Castro enforced Hemingway to departure Finca Vig.

As Hemingway aged, more problems came forward. The text style, once renowned, looked habitually to incline into self-parody. Judgment changed against him. His book Across the River and into the Trees was extensively criticized.

Bodily pain worsened his alcohol consumption and robbed him of his ability to work. Hemingway suffered psychological wounds during his childhood that predated by many years the traumatic experiences he encountered in World Wars I and II and all his subsequent injuries. The bipolar mood disorder he inherited from his family had plagued him all of his life with painful, abnormal mood states. His chronic alcoholism put him at greater risk of depression even as he struggled in vain to use this toxic drug to treat himself. Hemingway's life can be considered not only a tragedy, but also a story of triumph. Hemingway was destroyed, even by his own hand, but not defeated.

Viewing Fitzgerald's work in the wider context of illness literature clears that Fitzgerald wrote about the medical profession because he recognized the appeal of medical fiction to the mainstream reader. By examining the world of healthcare, he was examining his own health by extension. The lengths to which he continued to embrace healthcare elements in stories throughout the rest of his career speaks to a strong need to process these experiences and suggests he did not write about the medical world only because he recognized it as a marketable material.

Finally it can be concluded that illness had a straight effect on Fitzgerald's core identity, which centered on his ability to publish and write. Despite the public failure of several of his work, Fitzgerald's reflective urges helped him negotiate the darkest period of his life. As a result, although Fitzgerald may not have consciously desired to process his experiences in order to facilitate healing what nonetheless resulted from the consistent exploration of his own suffering. The stories of the 1930s show the breadth and depth of Fitzgerald's interest in healthcare topics and secure Fitzgerald's place as an American writer who pushed depictions of illness-commercial and literary, autobiographical and fictional into the public sphere.

\section{References}

1. Flaherty AW (2005) Fronto temporal and dopaminergic control of idea generation and creative drive. J Comp Neurol 493: 147-153.

2. Hemingway EM (1964) A moveable feast. Charles Scribner's Sons, New York.

3. Reynolds M (1986) The young Hemingway. Basil Blackwell, UK.

4. Lynn KS (1987) Hemingway. Simon \& Schuster, New York.

5. Mellow JR (1992) Hemingway: A life without consequences. Houghton Mifflin, Boston.

6. Burgess A (1978) Ernest Hemingway. Thames \& c Hudson, New York.

7. Baker C (1969) Ernest Hemingway: A life story. Charles Scribner's Sons, New York.

8. Hemingway EM (1929) A Farewell to Arms. Charles Scribner's Sons, New York.

9. Swaine J (2011) Ernest Hemingway driven to suicide over FBI suvillance.

10. Tate MJ (1998) F. Scott Fitzgerald A-Z: The essential reference to his life and work. Checkmark Books, New York.

11. F. Scott Fitzgerald. Shmoop biography.

12. Bryer J, Waldorn A (1996) The cartoonist, the nurse and the writer: An alcoholic case. University of Missouri, Missouri.

13. Ker L (2012) A lost decade: exploring F Scott Fitzgerald's contribution to the illness canon through the doctor-nurse series and other healthcare stories of the 1930s. Med Humanit, 38: 83-107.

14. Bruccoli MJ, Baughman J (2003) Asheville Citizen: F. Scott Fitzgerald staying at hotel here. In: Bruccoli MJB, Aughman J (Eds.) Conversations with Fitzgerald Jackson. University Press, Mississippi.

15. Bruccoli MJ (1981) Some Sort of epic grandeur. Harcourt Brace Jovanovich, New York.

16. Bryer JR, Petry AH (1996) Recovering the lost decade. In: Bryer JR, ed. New Essays on Fitzgerald's Neglected Stories. Missouri University of Missouri Press, Columbia.

17. Scott FF (1978) The Notebooks of F. Scott Fitzgerald. Bruccoli Clark, New York.

18. Scott FF. The last tycoon study guide \& Plot. Synopsis.

19. Scott FF (1945) The crack-up. New Directions, New York.

20. Harold B (2006) F. Scott Fitzgerald. Chelsea House Publishers, New York.

21. Fitzgerald FS (2011) Dreams of youth: the letters of F. Scott Fitzgerald. Little Books, London.

22. Matthijs B, De Dreu CK, Bernard AN (2008) A meta-analysis of 25 years of mood-creativity research: Hedonic tone, activation, or regulatory focus?. Psychological Bulletin 134: 779-806.

23. Mark AD (2009) Understanding the relationship between mood and creativity: A meta-analysis. Organizational Behavior and Human Decision Processes 100: 25-38.

24. Nemotoa T, Yamazawaa R, Kobayashia H, Fujitaa N, Chinoa B, et al. (2009) Cognitive training for divergent thinking in schizophrenia: A pilot study. Progress in Neuro-Psychopharmacology and Biological Psychiatry 33: 1533-1536.

25. Fitzgerald FS (1939) The lost decade: Short stories from esquire. Cambridge University Press, Cambridge. 